\title{
The Effect of The Flour of Soursop and Seed (Annona muricata) Againt The Mortality and The Reproduction of The Callosobruchus analis F. at the Soy Bean and the Mung Bean
}

\author{
Yos Wahyu Harinta \\ Universitas Veteran Bangun Nusantara \\ Sukoharjo, Indonesia \\ yoswahyu@yahoo.com
}

\author{
Agung Setyorini \\ Universitas Veteran Bangun Nusantara \\ Sukoharjo, Indonesia \\ agung.setyarini@yahoo.co.id
}

\begin{abstract}
- from a kind of method of a pest control after the used harvest up to now is by using chemical substance. When to be seen from the aspect of the population emphasis, thah method can certainly succeed fast, but from the aspect of ecology on the contrary can lead negative effect. The method of expexted control is practical, simple, economic and not dangerous. One of the probability is by using the flour of leaf and the flour of soursop seed (Annona muricata) for controlling the storehouse pest. This research was aimed : to know the effect of the Flour of soursop and Seed (Annona muricata) to the mortality and development of Callosobruchus analis on soybean and mung bean seeds, to know the effect of the flour of soursop and seed (Annona muricata) on damage and wight reduction of soybean and mung bean seeds, to gain the most effective dose of the Flor of soursop and Seed (Annona muricata) for controlling $C$. analis on soybean and mung bean seeds, and the know the posibility of interaction between the kinds of beans, the kinds and doses of the powders on the mortality and development of Callosobruchus analis. The research use Split-Split Plot Design with the RCBD as a basic one. Results of the research performed that the powders of the Flour of soursop and Seed (Annona muricata) to the mortality and development of Callosobruchus analis on soybean and mung bean seeds, these powders could reduce damage and wight reduction of soy bean and mung bean seeds from $C$. analis attack. The most effective doses of the powders of the Flour of soursop and Seed (Annona muricata) for controlling $C$. analis on soybean and mung bean seeds were not detected. There was no interaction between the treatments to the mortality and development of. $C$. analis.
\end{abstract}

Keywords-the flour of soursop and seed (annona muricata); the powder of the beatle callosobruchus analis $F$.

\section{INTRODUCTION}

Three of the most important legume crops in Indonesia are soybeans, peanuts and green beans. Soybeans are food crops that can be used as food ingredients, industrial raw materials, and animal feed ingredients. The multipurpose nature of soybeans causes soybean needs to continue to increase, along with population growth and the development of soy-based raw food industries. Soy protein content reaches $34 \%$ which is classified as high enough to attract the public as a relatively inexpensive source of vegetable protein [1]. Mung beans can be used as complementary with rice, because the lysine content in Mung beans is higher than rice. Some other advantages possessed by green beans are classified as early maturing plants (55-65 days), drought tolerant, and can be planted in less fertile areas so that potential is developed in suboptimal lands [2].

Crops stored in storage (warehouse) can be damaged by pests and diseases. Organisms that attack commodities in storage generally consist of groups of insects, rats and birds. Insects are the most destructive organisms in material or material stored. A total of around 700,000 types of insects, known to 100 species associated with savings materials and about 20 types of them are pests that live and breed in deposits so that they can damage storage materials [3]. Warehouse pest attack is one of the obstacles in storing crops. These pests can damage crops such as pods or seeds in storage and in the field before harvest [4].

Post-harvest pest control has been carried out in various ways, both physically, chemically, biologically and integrated pest control systems that combine various methods of pest control. The use of chemicals is a method of controlling post-harvest pests that are considered to be the most efficient and commonly carried out, using synthetic insecticides. Synthetic insecticides are considered more effective because their use is easy and their power spectrum is broad. However, on the other hand this method has many shortcomings because it can endanger humans and other living things. In addition, synthetic insecticides can cause pest resistance in plants in the long term. The use of insecticides in the context of controlling Plant Pest Organisms (OPT) is the last alternative, and the impact must be minimized, this is based on Government Regulation No. 6 of 1995 Chapter II in article 19. Therefore, it is necessary to find an effective way of controlling pest targets, but safe for non-target organisms and the environment [5].

One alternative that can be used to overcome the disadvantages of synthetic insecticides is to use organic / natural insecticides. Organic insecticides are insecticides whose basic ingredients come from plants (botanical pesticide), are local wisdom of the Indonesian people, because since time immemorial our ancestors have used it to control plant pest organisms. Indonesia is a country that has the second largest wealth of biodiversity (mega biodiversity) in the world after Brazil, has thousands of plants that contain insecticidal properties that can be used as basic ingredients for making organic insecticides [6]. 
The use of natural insecticides is relatively non-toxic to humans, animals and other plants because they are easily biodegradable so they do not cause residual effects [7]. Plants produce secondary metabolic compounds that can be repellent, food inhibitors (antifeedant/feeding deterrent), egg laying inhibitors (oviposition repellent/deterrent) and can also be toxic compounds to quickly kill insects [5]

Several types of plants that have the potential to be used as vegetable insecticides. The use of kluwih leaf flour (Artocarpus communis F.) at a dose of $1 \mathrm{~g} / 100 \mathrm{~g}$ of mung bean seeds is effective in controlling $C$. chinensis $L$. (bean powder beetle) and the use of red chili flour (Capsicum annum L.) with a dose of $1 \mathrm{~g} / 100 \mathrm{~g}$ soybean seeds are effective in controlling soybean powder beetles $(C$. analyst $F$.) in storage [8]. Other plant materials that are caged as vegetable insecticides are soursop leaves and seeds (Annona muricata L.). Plants belonging to the Annonaceae family contain bioactive annonan and acetogenin, which can act as insecticides, larvicides, repellents, and antifeedants. Anti feedent or anti-eating in soursop leaves due to the content of acetoginin compounds, including asymisin, roundacin, and squamosin. This situation makes pests not excited to eat the food they like. However, at low temperatures, acetogenin compounds can be toxic to pests causing death. In addition to the raw leaves, roots and soursop fruit also contains annonain chemical compounds. Soursop leaves and seeds can act as insecticides, larvicides, repellent (insect repellents) and anti feedent (food inhibitors) by smoothing the leaves and seeds, then mixed with solvents. The way it works as a contact and stomach poison [9].

Based on the results of the study, soursop (both seeds and leaves) should be developed and processed into environmentally friendly and economic value bio insecticides [10]. From various kinds of research on the use of soursop leaves as bio-insecticides but have never been tried on warehouse pests, especially in the pest Callosobruchus analyst $F$ which attacks soybeans and mung beans.

\section{MATERIALS AND METHODS}

\section{A. Material and Instrument}

The soybean seed and the small mung bean seed (Vigna radiata $L$.) the flour soursop leaf and the flour soursop seed with more small particicle or the same with 60 mesh and the beetle insect Callosobruchus analis $F$. The used instrument is : plastic jug, hand counter, digital scales, filter, reaction tube, brush, plastic plate, blender and label paper.

\section{B. Method of Research}

\section{The tried factor}

The factor is the flour soursop leaf and the flour soursop seed

\section{The plan of experiment}

The use plan is Split-split Plot Design with the basic plan of RCBD. As a Main treatment is Soy bean (A) Small green pea (B) ; THE Sub-treatment is the flour of soursop leaf (I) and the flour of soursop seed (II) and as the Subs of treatment is the dosage of flour $(0,1,2,3)$.

\section{The Observed Parameter}

The observed parameter on this research, i.e.: the pecentage of the imago mortality; the amount of the laid eggs; the amount of the egg that cracks become imago; the precentage of damage of seed; the percentage of damage of the seed weight.

\section{Framework}

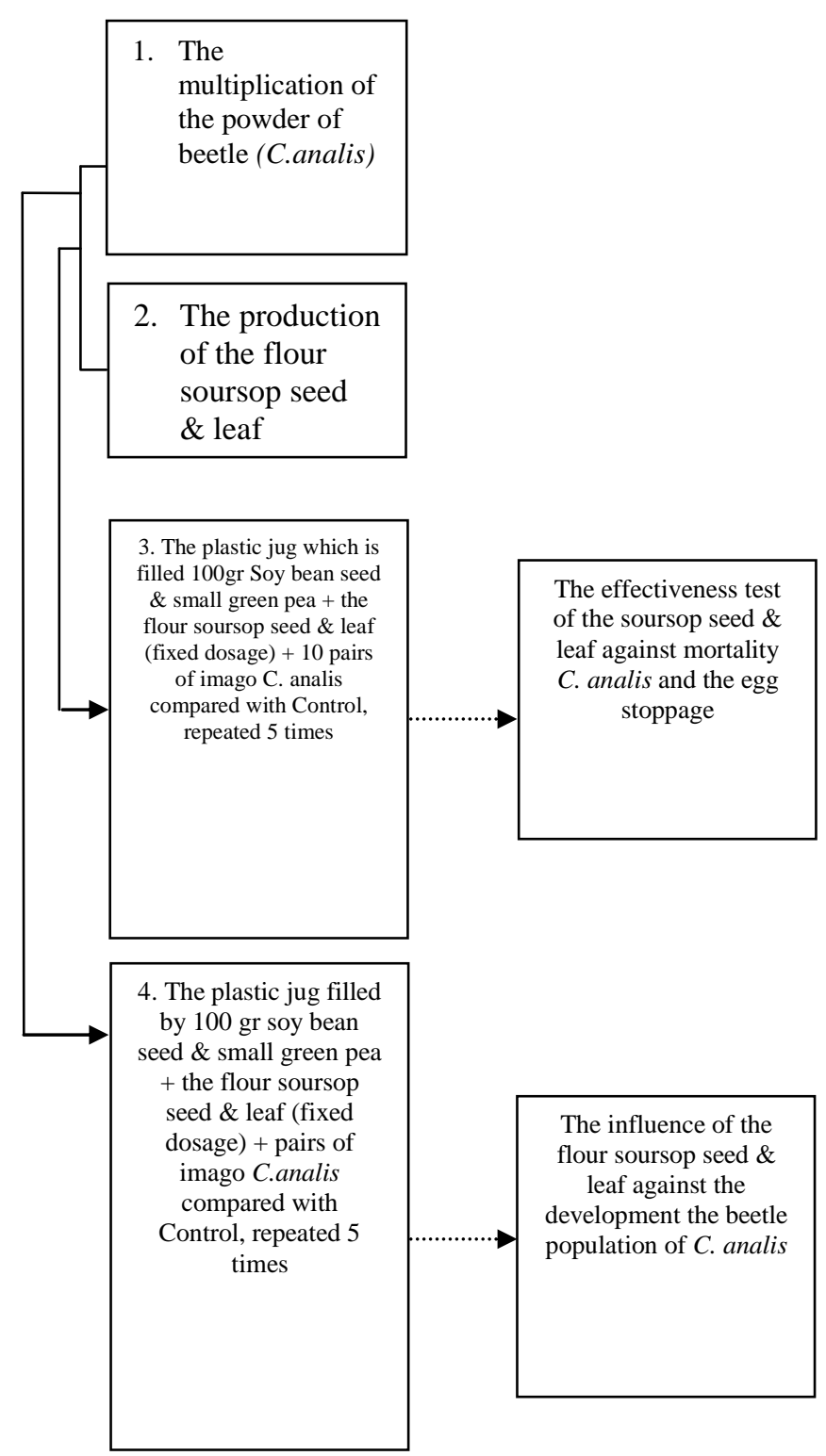

Fig. 1. Framework in this study

The work method of this research has been seen in the sketch of the current research, with phase :

1. The multiplication of the powder of beetle Callosobruchus analis F.

2. The production of the flour soursop seed and leaf (Annona muricata)

3. The effectveness of the soursop seed and leaf against the beetle mortality $\mathrm{C}$. analis and the egg stoppage 
4. The influence of the flour soursop seed and leaf against the development of the beetle population C. Analis

\section{E. The Method of Analysis}

The obtained date are analyzed by a kind of investigation test " $F$ ",Afterward if the result are showing real or very real difference, it can be done with the Test of Honesty Statement Difference (HSD) of the five percent phase.

\section{RESULT AND DISCUSSION}

\section{A. The Influence of The Flour Soursop Seed and Leaf} Against Mortality of Imago C. analis

Based on the result of the HSD test on the five percent phase showing that mortality of imago $C$. analis on three and five after tratment, on the tretment of a kind of bean; a kind of flour and dosage of tried flour is different really. On the tretment a) A kind of bean that different really, itis presumed becaouse of a kind of the flour soursop seed and leaf is more stick on the bean so that manier imago $C$. analis that are dead (the mortality is higher on soy bean if compared with small green pea), b). A kind of flour is different really against the mortality imago C. analis, it is presumed because the flour of soursop leaf is more stick of the bean family, so that it can resulth mortality imago $C$. analis is higher if compared with the flour soursop seed, c). the tretment of dosage of the flour 1,00 gr per 100 gr is different really with the others and control (Table 1).

TABLE 1. THE INFLUENCE OF THE FLOUR SOURSOP SEED AND LEAF AGAINST MORTALITY IMAGO C. ANALIS IN THREE OR FIVE DAYS AFTER TRETMENT

1. Main treatment

\begin{tabular}{llc}
\hline \multirow{2}{*}{ Kind of bean } & \multicolumn{2}{l}{ Mortality imago C. analis (\%) on } \\
\cline { 2 - 3 } & 3 dat & 5 dat* \\
\hline Soy Bean (A) & $8,700 \mathrm{a}$ & $12,015 \mathrm{a}$ \\
Mung Bean (B) & $7,371 \mathrm{~b}$ & $10,686 \mathrm{~b}$
\end{tabular}

Note: The numerals which are followed by the same letter in the same coloumn is not real different on $5 \%$ phase based on HSD test

$*$ dat $=$ day after tretment

2. Sub treatment

\begin{tabular}{lll}
\hline \multirow{2}{*}{ Kind of flour } & \multicolumn{2}{l}{ Mortality imago C. analis (\%) on } \\
\cline { 2 - 3 } & 3 dat & 5 dat* $^{*}$ \\
\hline $\begin{array}{l}\text { The flour soup } \\
\text { leaf (I) }\end{array}$ & $7,716 \mathrm{~b}$ & $10,150 \mathrm{~b}$ \\
$\begin{array}{l}\text { The flour soup } \\
\text { seed (II) }\end{array}$ & $6,500 \mathrm{a}$ & $9,817 \mathrm{~b}$
\end{tabular}

Note: The numerals which are followed by the same letter in the same coloumn is not real different on $5 \%$ phase based on HSD test
3. Sub-Sub treatment

\begin{tabular}{lcc}
\hline \multirow{2}{*}{$\begin{array}{l}\text { Dosage } \\
(\mathrm{gr} / 100 \mathrm{gr})\end{array}$} & \multicolumn{2}{c}{ Mortality imago C. analis (\%) on } \\
\cline { 2 - 3 } & $0,000 \mathrm{c}$ & 5 dat* \\
\hline $0,00(0)$ & $0,000 \mathrm{c}$ & $13,260 \mathrm{~b}$ \\
$0,50(1)$ & $14,295 \mathrm{~b}$ & $15,359 \mathrm{~b}$ \\
$0,75(2)$ & $17,848 \mathrm{a}$ & $18,568 \mathrm{a}$ \\
$1,00(3)$ &
\end{tabular}

Note: The numerals which are followed by the same letter in the same coloumn is not real different on $5 \%$ phase based on HSD test

Mortality on dosage of flour treatment is presumed because the flour of soursop seed and leaf contain specific mixture. Alkaloid and terpenoid compounds are very potential as food inhibitors and are toxic so that they can cause larval death. Metabolic disorders may also be caused by the presence of tannin compounds in insect foods which can interfere with the activity of insect digestive enzum (Mawuntu, 2015). Soursop leaves contain chemical compounds, among others: flavonioids, saponins, and steroids which at high concentrations have features as stomach poisons that cause pests to die [11].

Imago C. analis, which was infused into soybean mixture with soursop seed flour, will enter the sidelines of the mixture. Furthermore, the analyst C. analis will intersect with soursop seed flour. This allusion is thought to cause pain in the insect's cuticle. C. analis imago mortality due to the treatment of soursop seed flour is thought to be due to the presence of acetogenins. Acetogenins compounds have the potential as inhibitors in the process of cell respiration. As a result, the ATP formation process will not run properly so that the organism will not be able to obtain enough energy to meet its metabolic needs, which will cause the death of the organism [12]. There is a difference in mortality in the treatment of flour doses tried may be due to differences in dosage. With increasing doses, the penetration of flour will increase, so mortality will increase.

Based on the results above it turns out that an effective dose of flour has not been obtained to control the C. analyst image, because it has not caused 80 percent mortality. This is in accordance with the opinion Mumford \& Norton, (1984) cit [13], stating that an insecticide is considered effective if it can reduce the pest population by at least 80 percent or the development of pest populations to be less than 20 percent.

\section{B. The Influence of The Flour Soursop Seed Against The Development of Imago C. analysis}

1. The amount of laid eggs of female imago C.analysis and imago thay cracked

Base on the result of the test of Honest, Statement, Difference (HSD) on phase of unrealiable 5 percent indicates that the amount of laid eggs of female imago C.analysis and the amount of gone out imaho in 5 days after treatment, all tried treatment are real different. On the treatment : a) A kind of bean is real different, it is more sticky on soy bean seed so that more imago C.analysis dead (mortality is higher on soy bean seed if 
it is compared on small green pea), it results the amount of laid eggs on soy bean seed become less, b) A kind of flour is real different against the mortality of imago C.analysis, it is presumed because the flour soursop leaf more sticky on the bean family, so that it can result for mortality of imago C.analysis higher if ot is compared with the flour soursop seed, it results the amount of laid eggs than the flour soursop leaf is less, c) the treatment of the dosage of flour 1,00 gr per $100 \mathrm{gr}$ is real different with the other and controlling the amount of laid eggs of female imago C.analysis im the treatment of dosage 1,00 gr per 100 gr is real different with the other dosage or let's control (Table 2).

From the average of amount of laid eggs can be known that control is higher than the treatment with dosage of the floir soursop seed and leaf. This case is presumed because gift the flour soprsop seed and leaf could distrub the laying eggs, because that flour has mixtured and soiled the surface of soybean seed, so that it is difficult to the female imago C.analysis to decide the place that matches for laying. Soursop pesticides do not kill pests quickly, but have an effect on reducing appetite, growth, reproductive power, the process of changing the skin, barriers to becoming an adult insect, as a booster, disrupting and inhibiting insect mating, inhibiting laying and decreasing hatching and working systemically and control and easily absorbed. Furthermore, with the increasing dose given will result in a decrease in the number of eggs laid. This is due to the increasing dose will lead to higher mortality, so that the number of eggs placed decreases [9].

Furthermore by more ascending given dosage will result the decline of amount laid egg. This matter is caused by more and more rising dosage that will result the higher mortality, so that the amount of laid egg less.

TABLE 2. THE INFLUENCE OF THE FLOUR SOURSOP SEED AN LEAF AGAINST THE AMOUNT OF LAID EGGS OF FEMALE IMAGO AND THE AMOUNT OF GONE OUT IMAGO C.ANAYSIS IN 5 DAYS AFTER TREATMENT

a. Main treatment

\begin{tabular}{|c|c|c|}
\hline Kind of bean & $\begin{array}{l}\text { Amount of laid } \\
\text { eggs }\end{array}$ & $\begin{array}{l}\text { Amount of } \\
\text { gone out } \\
\text { imago }\end{array}$ \\
\hline Soy Bean (A) & $316,542 \mathrm{~b}$ & $269,625 \mathrm{~b}$ \\
\hline Mung Bean (B) & $395,375 \mathrm{a}$ & $350,458 \mathrm{~b}$ \\
\hline
\end{tabular}

Note: The numerals which are followed by the same letter in the same column is not real different on $5 \%$ phase base on HSD test

b. Sub treatment

\begin{tabular}{llll}
\hline Kind of bean & $\begin{array}{l}\text { Amount of laid } \\
\text { eggs }\end{array}$ & $\begin{array}{l}\text { Amount } \\
\text { gone } \\
\text { imago }\end{array}$ & $\begin{array}{r}\text { of } \\
\text { out }\end{array}$ \\
\hline The flour soup & $338,375 \mathrm{~b}$ & $295,708 \mathrm{~b}$
\end{tabular}

leaf (I)
The flour soup 373,544 a seed (II)

324,375 a

Note: The numerals which are followed by the same letter in the same column is not real different on $5 \%$ phase base on HSD test

c. Sub-Sub treatment

\begin{tabular}{lcc}
\hline Kind of bean & $\begin{array}{l}\text { Amount of laid } \\
\text { eggs }\end{array}$ & $\begin{array}{l}\text { Amount of } \\
\text { gone out } \\
\text { imago }\end{array}$ \\
\hline $0,00(0)$ & $421,500 \mathrm{a}$ & $418,083 \mathrm{a}$ \\
$0,50(1)$ & $360,833 \mathrm{a}$ & $296,667 \mathrm{~b}$ \\
$0,75(2)$ & $334,776 \mathrm{~b}$ & $277,417 \mathrm{c}$ \\
$1,00(3)$ & $298,500 \mathrm{c}$ & $246,000 \mathrm{~d}$
\end{tabular}

Note: The numerals which are followed by the same letter in the same column is not real different on $5 \%$ phase base on HSD test

2. Persentage of the damage of seed and reduction of seed weight

Base on the result of the fest of Honest, Statement, Difference (HSD) on phase of unreliable 5 percent, all tried treatment of influence against amount eggs that hatching into imago are real different. On the treatment:

a. It kind of bean is real different, it is presumed because a kind of the flour soursop seed and leaf is because a kind of the flour soursop seed and leaf is more sticky on soybean seed so that more imago C. Analysis dead (mortality is higher on soybean seed if is compared on mung bean), it results the amount of laid eggs on soybean seed become less,

b. It kind of lour is real different against the mortality of imago C. Analysis, it is presumed because the flour soursop leaf more sticky on the bean family, so that it can resut for the mortality of imago C. analysis higher if at is compared with flour soursop seed, it results the amount of laid eggs in the flour soursop leaf is less, it results damage of bean family seed in the flour soursop leaf is less

c. Percentage of the damage of seed and reduction of seed weight at the treatment to dosage of flour 1,00 gr per $100 \mathrm{gr}$ is real different with the other dosage or control (Table 3). From the above result it is obtained that the treatment by dosage 1,00 gr per 100 gr indicating best product. According Suyono dan Naito (1990) cit [6], the percentage of damage of bean family seed caused by attack C. analys more and more low so that the degree of population become low.

TABLE 3. THE INFLUENCE OF THE FLOUR SOURSOP SEED AGAINST THE DAMAGE OF SEED AND REDUCTION OF SEED WEIGHT

a. Main treatment

\begin{tabular}{llll}
\hline Kind of bean & $\begin{array}{l}\text { Amount of laid } \\
\text { eggs }\end{array}$ & $\begin{array}{l}\text { Amount } \\
\text { gone }\end{array}$ & $\begin{array}{r}\text { of } \\
\text { out }\end{array}$
\end{tabular}


imago

\begin{tabular}{lll}
\hline Soy Bean (A) & $23,365 \mathrm{a}$ & $3,919 \mathrm{a}$ \\
Mung Bean (B) & $26,963 \mathrm{~b}$ & $3,542 \mathrm{~b}$
\end{tabular}

Note: The numerals which are followed by the same letter in the same column is not real different on $5 \%$ phase base on HSD test

b. Sub treatment

\begin{tabular}{llll}
\hline Kind of bean & $\begin{array}{l}\text { Amount of laid } \\
\text { eggs }\end{array}$ & $\begin{array}{l}\text { Amount } \\
\text { gone } \\
\text { imago }\end{array}$ & $\begin{array}{r}\text { of } \\
\text { out }\end{array}$ \\
\hline $\begin{array}{l}\text { The flour soup } \\
\text { leaf (I) }\end{array}$ & $24,035 \mathrm{a}$ & $3,611 \mathrm{a}$ & \\
$\begin{array}{l}\text { The flour soup } \\
\text { seed (II) }\end{array}$ & $26,292 \mathrm{~b}$ & $3,849 \mathrm{~b}$ &
\end{tabular}

Note: The numerals which are followed by the same letter in the same column is not real different on $5 \%$ phase base on HSD test

c. Sub-Sub treatment

\begin{tabular}{lcc}
\hline Kind of bean & $\begin{array}{l}\text { Amount of laid } \\
\text { eggs }\end{array}$ & $\begin{array}{l}\text { Amount } \\
\text { gone } \\
\text { imago }\end{array}$ \\
\hline $0,00(0)$ & $34,287 \mathrm{a}$ & $\begin{array}{r}\text { of } \\
\text { out }\end{array}$ \\
$0,50(1)$ & $24,253 \mathrm{~b}$ & $3,811 \mathrm{~b}$ \\
$0,75(2)$ & $22,376 \mathrm{c}$ & $3,522 \mathrm{c}$ \\
$1,00(3)$ & $19,731 \mathrm{~d}$ & $3,229 \mathrm{~d}$ \\
\hline
\end{tabular}

Note: The numerals which are followed by the same letter in the same column is not real different on $5 \%$ phase base on HSD test

The low percentage of seed damage will reduce the shrinkage of seed weight. This is due to the lack of damaged seeds (the same number of seeds per gram), the lower the weight caused by the seeds. According to Soekarna (1982) cit [4], the amount of damage and shrinkage of seed weight in storage places depends on the high and low density of insect populations. In increasingly dense populations, the weight and shrinkage of seed weight increases.

\section{CONCLUSION}

The flour soursop seed and leaf with dosage 1,00 gr/100 gr seed can influence on increasing mortality and decreasing the growth of the beetle Callosobruchus analysis $F$. on the soybean in the saving place, and it can reduce the damage and reduction of the seed weight caused by the attack of beetle Callosobruchus analysis F. in the saving, moretheles it has not yet obtained a dosage of soursop leaf and seed flour effectively in controlling the beetle Callosobruchus analysis $F$. it is not found the effect of interaction between all treatments against mortality and development Callosobruchus analysis $F$.

\section{ACKNOWLEDGMENT}

This research was supported by LPPM Veteran Bangun Nusantara University of Sukoharjo for internal researchers' grants 2018 .

\section{REFERENCES}

[1] Nuhung, I. A. Kedelai dan Politik Pangan. Forum Penelitian Agro Ekonomi, 31(2), 123-135. Retrieved from pse.litbang.pertanian.go.id, 2013.

[2] Trustinah, Radjit, B. S., Prasetiaswati, N., \& Harnowo, D. Adopsi Varietas Unggul Kacang Hijau di Sentra Produksi. Iptek Tanaman Pangan, 9(1), 24-38, 2014.

[3] Rimbing, S. C. Keanekaragaman Jenis Serangga Hama Pasca Panen Pada Beberapa Makanan Ternak di Kabupaten Bolaang Mongondow. Jurnal Zootek, 35(1), 164-177, 2015.

[4] Nonci, N., \& Muis, A.. Biologi, Gejala Serangan, dan Pengendalian Hama Bubuk Jagung Sitophilus zeamais Motschulsky (Coleoptera; Curculionidae). Jurnal Litbang Pertanian, 34(2), 61-70, 2015.

[5] Hasnah, Rahim, M., \& Suryanti, L. Efikasi Serbuk Lada Hitam dalam Mengendalikan Hama Sitophilus zeamais pada Biji Jagung Selama Penyimpanan. Jurnal Penelitian Universitas Jambi Seri Sains, 16(2), 23-32, 2014

[6] Budiyanto, M. A. K., Muizuddin, \& Hadi, S. Efektivitas Pendampingan dalam Produksi dan Pengunaan Insektisida Organik di Kelompok Tani Sumber Urip Malang. In Proceeding Biology Education Conference (Vol. 13, pp. 643-648). Surakarta, 2016.

[7] Puspitosari, D., Rochman, N., \& Tobing, O. L. Daya Insektisidal Minyak Nilam (Pogostemon cablin Benth) dan Ekstrak Lerak (Sapindus rarak DC.) pada Hama Gudang Sitophilus zeamais (Motsch.). Agronida, 1(1), 1-10, 2015.

[8] Harinta, Y. W. Efektifitas Tepung Daun Sirsak (Annona muricata) untuk Mengendalikan Kumbang Bubuk Kedelai (Callosobruchus analis F.) pada Biji Kedelai (Glycine max L.). Agrivigor, 6(2), 121-127, 2013.

[9] Kardinan, A. Penggunaan Pestisida Nabati Sebagai Kearifan Lokal Dalam Pengendalian Hama Tanaman Menuju Sistem Pertanian Organik. Pengembangan Inovasi Pertanian, 4(4), 262-278, 2011.

[10]Suranto, A. Dahsyatnya Sirsak Tumpas Penyakit. Jakarta: Pustaka Bunda, 2011.

[11] Desiyanti, N. M. D., Swantara, I. M. D., \& Sudiarta, I. P. Uji Efektivitas dan Identifikasi Senyawa Aktif Ekstrak Daun Sirsak sebagai Pestisida Nabati Terhadap Mortalitas Kutu Daun Persik (Myzus persicae Suiz) pada Tanaman Cabai Merah (Capsipcum annum L.). Jurnal Kimia, 10(1), 1-6, 2016.

[12] Afidah, R., Yuliani, \& Haryono, T. Pengaruh Kombinasi Filtrat Umbi Gadung, Daun Sirsak, dan Herba Anting-Anting terhadap Mortalitas Larva Ordo Lepidoptera. LenteraBio, 3(1), 45-49, 2014.

[13] Harinta, Y. W., R, N., \& Setyorini, A. Pengendalian Hama Bubuk Kedelai (Callosobruchus analis F.) dengan Biji Sirsak (Annona muricata). Agrin, 20(1), 81-91, 2016. 